\title{
Lusioersily
}

\section{Coastal Morphodynamics: Nearshore, beach and dunes}

Guisado-Pintado, E., Jackson, DWT., \& Delgado-Fernandez, I. (2020). Coastal Morphodynamics: Nearshore, beach and dunes. Earth Surface Processes and Landforms, 45(5), 1315-1317. https://doi.org/10.1002/esp.4824

Link to publication record in Ulster University Research Portal

\author{
Published in: \\ Earth Surface Processes and Landforms
}

Publication Status:

Published (in print/issue): 01/04/2020

DOI:

10.1002/esp.4824

\section{Document Version}

Author Accepted version

\section{General rights}

Copyright for the publications made accessible via Ulster University's Research Portal is retained by the author(s) and / or other copyright owners and it is a condition of accessing these publications that users recognise and abide by the legal requirements associated with these rights.

\section{Take down policy}

The Research Portal is Ulster University's institutional repository that provides access to Ulster's research outputs. Every effort has been made to ensure that content in the Research Portal does not infringe any person's rights, or applicable UK laws. If you discover content in the Research Portal that you believe breaches copyright or violates any law, please contact pure-support@ulster.ac.uk. 
Guisado-Pintado Emilia (Orcid ID: 0000-0003-1115-4059)

Jackson Derek W.T. (Orcid ID: 0000-0003-1778-2187)

\section{Coastal Morphodynamics: Nearshore, beach and dunes}

\section{Authors: Emilia Guisado-Pintado ${ }^{1,2}$; Derek W.T. Jackson²; Irene Delgado-Fernandez ${ }^{3}$}

${ }^{1}$ Department of Physical Geography and Regional Geographic Analysis, University of Seville, Seville 41004, Spain (eguisado@us.es).*Corresponding author.

${ }^{2}$ Centre for Coastal \& Marine Research, School of Geography \& Environmental Sciences, Ulster University, Northern Ireland, BT52 1SA (d.jackson@ulster.ac.uk).

${ }^{3}$ Department of Geography and Geology, Edge Hill University, St Helens Rd, Orsmkirk, Lancashire, L39 4QP, UK (delgadoi@edgehill.ac.uk).

Understanding coastal morphodynamics involves investigating a system of processes and landforms operating over variable spatial and temporal scales in a environment, where the hydrosphere, lithosphere and atmosphere meet to form one of Earth's most complex systems. Understanding its short- (event) to long-term (evolution) dynamics requires a multidisciplinary approach to investigate a diversity of coastal environments. Science-led management of sandy coastal systems must incorporate a comparative understanding of the morphodynamics operating at a range of sites to allow effective management to take place.

This special issue of Earth Surface Processes and Landforms (ESPL) arose from the inaugural session of Coastal Morphodynamics: Nearshore, Beach and Dunes at the 2017 European Geosciences Union meeting in Vienna, Austria. Co-sponsored by the IGU Commission on Coastal Systems, and supported by the British Society for Geomorphology (2017), the Session successfully assembled over 40 scientific contributions from various sub-sets of coastal science and covered a range of temporal and spatial scales. The diverse coastal environments and associated dynamics highlighted the need for an over-arching coastal morphodynamics themed special issue that helps bring together the various scales and behaviour of coastal morphodynamics. We have added to the Special Issue additional papers addressing this theme recently published by ESPL.

The longer term development of coastal landforms is neatly captured through observations of ridge construction on prograding coastlines. Herrero et al. (2019) examined the geometry and growth mechanisms of multiple ridges at Ria Formosa, Portugal where wave processes dominated over aeolian processes in their formation over a 70-year period. Progradation rates of beach ridges were shown to be related largely to longshore wave power, storminess, and the occurrence storm groups. However, their findings showed that establishing the relation between forcing and response is not a straightforward task due to the complexities of that control coastal morphodynamics. Miles et al.

This article has been accepted for publication and undergone full peer review but has not been through the copyediting, typesetting, pagination and proofreading process which may lead to differences between this version and the Version of Record. Please cite this article as doi: $10.1002 /$ esp.4824

This article is protected by copyright. All rights reserved. 
(2019) also working on longer-term morphodynamics examined nearshore bar movements in 3D using LiDAR within a macrotidal environment in the UK. Over a 17-year period the (3-4) bar positions were characterised for a $17 \mathrm{Km}$ stretch and showed distinct alignment with the predominant wave approach direction. The onshore moving bars were also shown to be narrower and steeper as they migrated onshore, mirroring wave shoaling, with results highlighting the importance of characterising nearshore bars as a 3D system. Preston et al. (2018) investigated how sediment accumulation in embayments can be affected by local bathymetry and available wave energy. Their work showed the profound implications for general beach formation and endurance of any beach that may form within a coastal compartment. Using numerical simulations, they defined a critical offshore slope where favourable beach forming potential occurs (under calm conditions). Along with storm conditions they demonstrated that beach recovery may be on decadal time scales and suggest a number of implications of having higher energy conditions in the past. Dodet et al. (2019) also examined beach recovery after the exceptionally high energy storm events of 2013/14 in Europe but over shorter (annual) timescales. Using a unique dataset of decadal beach morphological changes along the west coast of Europe they investigated recovery patterns at a number of sites. Their work demonstrated that a recovery signature was site-specific and multi-annual, with just one location fully recovered after 2 years, whilst others were only partially recovered after 4 years. Winter waves were the primary driving parameter in setting the timescale for restoration of beach volumes to prestorm amounts. With exposed beaches, the use of an equilibrium model worked well in reproducing post-storm recovery.

Green et al. (2019) showed that while the morphodynamics and physical structure of coastal barrier systems with persistent tidal inlets are relatively well studied, we know little about the stratigraphy and functioning of barrier systems with ephemeral inlets. Using Ground Penetrating Radar surveys over the barrier-inlet systems of two intermittently closed open lagoons or temporarily open closed estuaries on the east coast of South Africa they revealed an absence of migrating channel features and demonstrated that barriers often breach under high swell conditions and subsequently closed under fair weather wave conditions. Time series analysis of waves and satellite imagery shows a link between storms from the south and noted breach events. In the UK, Pile et al. (2019), examined an unusual barrier island system in that it was formed on a planated bedrock surface. The site on the western Scottish coast, presented a unique examination of the internal structure and morphology of these barrier islands and investigated the controls on their structure. Their work showed that episodic deposition of windblown sand (to water table height) with additional sand transported through the system to collect in lows such as lake fills, or on topographic highs as 'high machair'. Local bedrock topography and sediment supply are therefore deemed the dominant controls on variability in barrier structure. Zăinescu et al. (2019) showed that barrier evolution can be highly non-linear, with barrier breaching playing an important role on the landward migration of barrier systems. They investigated a large natural barrier breaching event at the Danube Delta, where a narrow section of the barrier breached and reached $3.4 \mathrm{~km}$ under relatively moderate storm conditions, hence highlighting the significance of pre-breaching barrier morphology. The event triggered complex changes in the direction and magnitude of sediment transport resulting in the natural closure of the breach just 3 years after the event. This study is also testament of the connection between short-term (event-scale) processes and longer-term (evolution) associated with coastal landforms.

Davidson-Arnott et al. (2018) investigated the morphological evolution of over six decades of foredune changes to help develop a simple computer model that simulates foredune growth. Their long-term data showed that even with steep foredune stoss faces sediment can still be transferred from the beach to the foredune, as oblique rather than onshore winds persist enough to negate the steeper slopes. Apparent growth rate appears to slow with time as the system adjusts to changing sediment supplies; dunes required more and more sediment to grow and they became limited by

This article is protected by copyright. All rights reserved. 
available sediment supply. Their study demonstrates that modelling can be simple but that modelling assumptions need to be realistic to avoid potential modelling artefacts. Foredune ridge plains can be built over much longer periods and the example from Pedro beach in Australia by Oliver et al. (2019) showed the various spatial and temporal phases such systems can undergo. Using GPR, LiDAR and OSL dating they unravelled the detailed history (7000 - 3900 years ago) of the dune ridge building showing a series of shoreline reorientations and ridge volume growth along with shoreface supply of sediment that changes over time. The complex interplay between wave regime, sediment supply and accommodation space is succinctly represented when the beach ridge plain is unravelled through the analysis undertaken. Gore et al. (2019) illustrate the high levels of beach diversity shown in tropical islands, where combinations of different geological frameworks, sediment source and availability, and exposure to waves and wind processes, give rise to a range of beach systems. By examining up to 100 beaches incorporating a wide range of variables (including coastline orientation, gradient or wave energy among others) the authors provided a classification that allowed systematic grouping of beaches in relation to primary factors that control their composition and form. Seasonal changes to wave and wind conditions were also shown to have played a secondary role in beach variability.

Sediment dynamics in the nearshore and shelf are important aspects of coastal morphodynamics, and in many cases represent important feeders of sediment supply for surf and beach zones. In the Mediterranean Sea, Malvarez et al. (2019) examined sediment interactions between the dunes and the shelf. The Cabopino dune system in the southern Spanish Mediterranean Sea provides a clear example of a linked morphodynamic system involving the nearshore, beach and terrestrial dune systems. At Cabopino, a relatively large dune system has been created largely through sediments from an adjacent littoral source. Malvarez et al. present a conceptual model of how the nearshore provided adequate conditions for beach and dune development, suggesting that synchronization of sediment activation in the marine and aeolian sections of the system has played an important role where temporal aspects of dune building are not only linked to storm action, but also to large sedimentary features moving alongshore from offshore sources.

This selection of papers highlights a range of spatial and temporal scales operating within coastal morphodynamics and touches upon the complexity associated with them. A number of techniques are used to isolate particular datasets to allow analysis of this short to long term behaviour of this system. As the effects of climate change and rising sea-levels become more prevalent over the next few years, there is an even greater need for investigations of how sandy coastlines change at a variety of temporal/spatial scales at sites globally.

\section{REFERENCES}

Davidson-Arnott, R., Hesp, P., Ollerhead, J., Walker, I., Bauer, B., Delgado-Fernandez, I. and Smyth, T., 2018. Sediment budget controls on foredune height: Comparing simulation model results with field data. Earth Surface Processes and Landforms, 43(9), pp.1798-1810. https://doi.org/10.1002/esp.4354

Dodet, G., Castelle, B., Masselink, G., Scott, T., Davidson, M., Floc'h, F., Jackson, D. and Suanez, S., 2019. Beach recovery from extreme storm activity during the 2013-14 winter along the Atlantic coast of Europe. Earth Surface Processes and Landforms, 44(1), pp.393-401. https://doi.org/10.1002/esp.4500

Gore, S., Cooper, J.A.G., Jackson, D.W. and Jarecki, L., 2019. Spatial variability in beach biogeomorphology in a tropical archipelago. Earth Surface Processes and Landforms. https://doi.org/10.1002/esp.4604 
Green, A.N., Pillay, T., Cooper, J.A.G. and Guisado-Pintado, E., 2019. Overwash-dominated stratigraphy of barriers with intermittent inlets. Earth Surface Processes and Landforms. https://doi.org/10.1002/esp.4631

Herrero, X., Costas, S. and Kombiadou, K., 2019. Coastal ridge constructive processes at a multidecadal scale in Barreta Island (southern Portugal). Earth Surface Processes and Landforms. https://doi.org/10.1002/esp.4742

Malvarez, G., Navas, F., Guisado-Pintado, E. \& Jackson, D.W.T. (2019) Morphodynamic interactions of continental shelf, beach and dunes: The Cabopino dune system in Southern Mediterranean Spain, Earth Surface Processes and Landforms 44, 1647-1658 10.1002/esp.4600 Miles, A., Ilic, S., Whyatt, D. and James, M.R., 2019. Characterizing beach intertidal bar systems using multi-annual LiDAR data. Earth Surface Processes and Landforms. https://doi.org/10.1002/esp.4594

Oliver, T.S., Tamura, T., Short, A.D. and Woodroffe, C.D., 2019. Rapid shoreline progradation followed by vertical foredune building at Pedro Beach, southeastern Australia. Earth Surface Processes and Landforms, 44(2), pp.655-666. https://doi.org/10.1002/esp.4510

Preston, J., Hurst, M.D., Mudd, S.M., Goodwin, G.C., Newton, A.J. and Dugmore, A.J., 2018. Sediment accumulation in embayments controlled by bathymetric slope and wave energy: Implications for beach formation and persistence. Earth Surface Processes and Landforms, 43(11), pp.2421-2434. https://doi.org/10.1002/esp.4405

Pile, J., Cooper, J.A.G. and Jackson, D.W.T., 2019. Stratigraphy and internal structure of winddominated barrier islands (dune and machair) of the Outer Hebrides, Scotland. Earth Surface Processes and Landforms, 44(7), pp.1482-1493. https://doi.org/10.1002/esp.4579

Zăinescu, F.I., Vespremeanu-Stroe, A. and Tătui, F., 2019. The formation and closure of the Big Breach of Sacalin spit associated with extreme shoreline retreat and shoreface erosion. Earth Surface Processes and Landforms, 44(11), pp.2268-2284. https://doi.org/10.1002/esp.4639 